\title{
Applying Genre-based Teaching Approach in Graduate English Reading Instruction
}

\author{
Yang Wenjing \\ Foreign Language School \\ Wuhan Media and Communications College of Huazhong Normal University \\ Wuhan, China \\ ywj482@126.cm
}

\begin{abstract}
Genre-based teaching approach is based on genre analysis, which applies the theory of genre and genre analysis to the classroom, and develops teaching activities revolving around the schematic structure of a text. This paper constructed an experiment based on the graduate English reading courses of China University of Geosciences and graduate English self-access learning system. The experiment selected two groups of nonEnglish majors, within 62 people for each group. The whole experiment lasted for a semester, implementing traditional teaching approach to the control group while genre-based teaching approaches to the experimental group. Through analyzing the pretest and posttest data, it proves that genre-based teaching approach is superior to traditional teaching approach.
\end{abstract}

Keywords-genre; genre analysis; genre-based teaching approach; graduate English reading

\section{INTRODUCTION}

It has become a popular framework for analyzing the form and function of nonliterary discourse, such as the research article, as well as a tool for developing educational practices in fields such as rhetoric, composition studies, professional writing, linguistics, and English for specific purpose (ESP). Since the birth of genre theory, many linguists and researchers have tried to employ them in teaching practice, based on which genre-based teaching approach came into being and has become very popular in North America and Australia. Genrebased teaching approach is based on genre analysis, which applies the theory of genre and genre analysis to the classroom, and develops teaching activities revolving around the schematic structure of a text. In recent years some linguists and teachers have begun to apply genre-based teaching approach to the teaching of English as a foreign language and have achieved sound results. However, their study mainly directs into the field of writing, and the study of its application to reading comprehension is very limited, which is the major concern of this paper.

\section{LITERATURE REVIEW}

\section{A. The Definition of Genre}

The word genre comes from the French (and originally Latin) word for "kind" or "class". Genre refers to abstract, socially recognised ways of using language. It is based on the assumptions that the features of a similar group of texts depend on the social context of their creation and use, and that those features can be described in a way that relates a text to others like it and to the choices and constraints acting on text producers.

Swales, as a practitioner of English for Specific Purposes, offers further explanations to the concept of genre and sees genre as: 1) a class of communicative events; 2) a shared set of communicative purposes; 3 ) being various in their prototypicality; 4) the schematic structure of the discourse shaped by certain rationale to confine its content, positioning, form and style; 5) an important source of insight reflecting a discourse community's nomenclature for genres [1]. Based on Swales' illustration of genre, Bhatia presents his own working definition of genre as follows: 1) Genre is a recognizable communicative event characterized by a set of communicative purpose identified and mutually understood by members of the professional or academic community in which it regularly occurs; 2) It most often is a highly structured and conventionalized communicative event; 3) Various genres display constraints on allowable contributions in terms of their intent, positioning, form and functional value; 4)These constraints are often exploited by the expert of the discourse community to achieve private intentions within the framework of socially recognized purpose(s) [2].

\section{B. Genre-based Teaching Approach}

There has been considerable interest in the genre-based approach to the teaching of language since the mid-1980s. This approach has communicative purpose as its foundation and originated through the work of Halliday [3], Swales, and Bhatia.

Genre-based teaching approach, in all its forms, involves some kind of classroom consideration of genres and the contexts in which they are found. This teaching approach has generally focused on written texts and been directed at writing classrooms, although some ESP researchers have recently discussed genre-based applications for EFL oral communication. Beyond these fundamentals, however, researchers in ESP, New Rhetoric, and Australian systemic functional linguistics have developed genre-based teaching approach in different directions and with different goals and education sites in mind [4]. From the present situation in genrebased teaching approach, we may see that this approach has mainly been explored and employed in academic writing, and 
the teaching of listening and reading have been given less attention.

In China, the theory of genre analysis and genre-based teaching approach was first introduced by Qin Xiubai. Since then, more and more researchers and teachers have become interested in them and tried to apply them to the practice of foreign language teaching [5]. Liang Wenhua explored ways to apply genre-based approach to English reading [6]. Huang Donghua studied to apply genre-based teaching methods in English writing [7].

\section{Methodology}

\section{A. Subjects Selection}

To fulfill the study purpose, the author conducted an experimental study in China University of Geosciences, Wuhan, Hubei. The experiment lasted for one term with two classes of graduate students in grade one participated, each consisting of 80 students respectively as the experimental group and the control group for their same level of English proficiency. As part of their degree program the students were required to take a term of English reading. Their English reading course consists 4 hours per week. These students had the similar experiences in learning English: they had studied English for nearly 10 years before entering the graduate school. Half of them were under intermediate proficiency level according to their entrance exam of graduate school.

The two classes are assigned to the author at random by the college. They belong to different departments but they learn the same subjects and use the same English textbooks for the term in the university. Class $\mathrm{A}$ is the experimental group, and class $\mathrm{B}$ is the control group. The teacher of the two groups is the present author's supervisor.

In the experimental class, the teaching model by genrebased approach was adopted purposely; in the control class, conventional teaching method was utilized as usual.

\section{B. Instruments}

The instruments used in this study were two reading comprehension tests as pre-test and post-test.

The tests were designed to assess students' reading ability and their comprehension level. Prior to the experiment, the pretest which was conducted at the beginning of the semester in September 2014 was given to both classes to see whether they were at the same level in reading competence. The post-test was taken by the classes after the experiment in December 2014 to determine their changes in reading comprehension over the study period. Statistics and data analysis were used to compare the scores by the two classes, and to see genre-based teaching approach was effective on students' English reading ability.

Both the pre-test and the post-test are selected from the newspapers and magazines of English language and they are easier than CET6 but more difficult than CET4.

The tests consist of 4 passages involved education narration, exposition and argumentation as education, technology and science problems. Each reading comprehension test contains 4 short passages, each passage with five multiple-choice questions; altogether there are 20 questions with each question occupying 5 points. And both reading comprehension tests are finished within a set time that is 35 minutes according to CET4 and CET6.

\section{Procedure}

The experiment was conducted from September 1, to December 30, 2014. The teacher instructed two classes with two different teaching methods using the same textbook (Intensive Multidimensional Course: Approaching Proficiency, Graduate English Series, High Education Press). The selfaccess reading materials were selected from other Graduate English Books.

\section{1) The Procedure of the Experiment}

A pre-test on reading proficiency containing four passages with multiple choices was held in two classes at the beginning of the new term, through which their reading ability to comprehend the reading material was judged. The purpose was to see whether the subjects were at the same level in reading competence before the experiment. The test was required to complete within 35 minutes.

The traditional approach is mostly employed in teaching class B, while the genre-based teaching approach is applied to class A. Both of the two groups take 4 periods per week, and use the same textbooks, but as for experimental group, the teacher arranged the book materials according to various genres.

Four months after the employment of genre-based teaching approach in class A, another reading comprehension test is given to all the students in class A and class B.

\section{2) The Procedure of the Teaching}

During the implementation of genre-based teaching, the teacher arranges self-access reading materials according to various genres. The textbook format is limited and various materials can be applied to multiple tasks and learning objectives. The self-access reading materials, when appropriately selected and implemented, can be used to develop tasks that depart from formulaic language learning and provide a bridge between the linguistic skills of learners and their professional knowledge goals. Such materials, in their various formats, can provide a wealth of linguistic and conceptual content to learners who are focused on specific applications of their linguistic skills. So self-access reading is essential, since it is what the students will encounter outside the classroom.

In the process of four-month genre-based teaching approach experiment, students are guided to analyze five genres, including narratives, argumentations, advertisements, news stories and introductions. The author tries to help the experimental group students to familiarize the five genres, which can facilitate to form a cognitive schematic structure in their memory.

There are a number of key ways in which a teacher, armed with the structural insights of a genre description, can use an explicit knowledge of text to provide guidance and constructive input. 
The teacher teaching procedure can be divided into 3 parts.

Part 1 :Introduce and discuss a genre with the students

Part 2 : Self-access reading

Part 3: Feedback by the teacher

\section{Data Collection and Analysis Procedure}

Data collection is conducted through the two reading comprehension tests, of which one is pre-test, the other is posttest. Scores are summed up according to the total number of participants' correct responses in the test.

The results of the reading achievements are inputted into computers, and Spss 19.0 statistical analysis is used to analyze them. The data are analyzed with the following statistical procedures: descriptive statistics (mean, standard deviation), and T-test.

\section{RESUlTS AND DISSUSION}

\section{A. The Influence of Genre-based Teaching Approach on Reading Achievements}

TABLE I. Group StATISTICS

\begin{tabular}{|l|c|c|c|c|c|}
\hline $\mathrm{T}$ & $\mathrm{N}$ & Mean & Std. Deviation & Std. Error Mean \\
\hline A & & & & 1.8796 \\
\hline Pretest & $\mathrm{A}$ & 62 & 47.0000 & 14.7998 & 1.5302 \\
& $\mathrm{~B}$ & 62 & 46.7581 & 12.0487 & 1.5706 \\
\hline Posttest & $\mathrm{A}$ & 62 & 53.4677 & 12.3670 & 1.7177 \\
& $\mathrm{~B}$ & 62 & 48.6290 & 13.5250 & $\mathrm{~B}$ \\
\hline
\end{tabular}

TABLE II. INDEPENDENT SAMPLES TEST

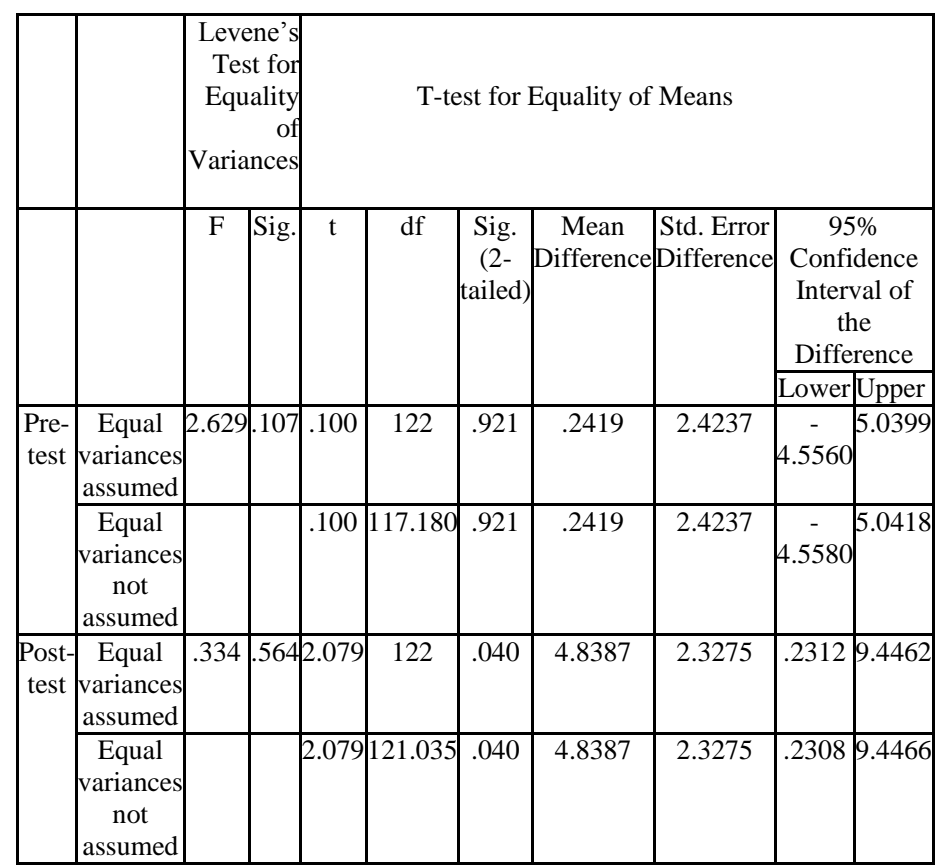

Table 1 and Table 2 show the descriptive statistics of the achievements of the two comprehension tests. These two tables indicate that the two classes do not demonstrate significant differences in the two comprehension tests achievement at the 1.9 level according to $T$ test. However, from the different mean scores, it can be concluded that class A achieved better results than class $\mathrm{B}$ in reading comprehension after being exposed to the genre-based teaching approach. Therefore, it is the different teaching approach that leads to different reading achievement. The fact that the $\mathrm{T}$ test doesn't demonstrate the significant differences of the two classes in achievement can be explained by the length of time available for the experiment. We believe the beneficial effects of genre-based teaching approach is measurable after a much longer period of instruction.

TABLE III. BETWEEN-SUBJECTS FACTORS

\begin{tabular}{|c|c|c|c|}
\hline \multicolumn{2}{|c|}{} & Value Label & N \\
\hline \multirow{2}{*}{ TA } & TA1 & A & 62 \\
\cline { 2 - 4 } & TA2 & B & 62 \\
\hline
\end{tabular}

TABLE IV. LEVENE's TEST OF EQUALITY OF ERROR VARIANCES (POSTTEST)

\begin{tabular}{|c|c|c|c|}
\hline F & df1 & df2 & Sig. \\
\hline .214 & 1 & 122 & .645 \\
\hline \multicolumn{2}{|c|}{} \\
Tests the null hypothesis that the error variance of the dependent variable is equal across groups.
\end{tabular}

a Design: Intercept+Pretest+TA+ TA* Pretest

It can be inferred accord to Table 5 that the following covariance analyzing results are effective as F=0.214 and Sig. $=0.645>0.05$.

TABLE V. Tests of BetweEn-SubJects EFFects (PostTest)

\begin{tabular}{|c|c|c|c|c|c|}
\hline Source & $\begin{array}{c}\text { Type III Sum of } \\
\text { Squares }\end{array}$ & $\mathrm{df}$ & Mean Square & $\mathrm{F}$ & Sig. \\
\hline $\begin{array}{c}\text { Corrected } \\
\text { Model }\end{array}$ & $3123.687(\mathrm{a})$ & 3 & 1041.229 & 6.907 & .000 \\
\hline Intercept & 11235.996 & 1 & 11235.996 & 74.534 & .000 \\
\hline Pretest & 2395.590 & 1 & 2395.590 & 15.891 & .000 \\
\hline TA & 233.251 & 1 & 233.251 & 1.547 & .216 \\
\hline TA*Pretest & 71.309 & 1 & 71.309 & .473 & .493 \\
\hline Error & 18090.023 & 120 & 150.750 & & \\
\hline Total & 344350.000 & 124 & & & \\
\hline $\begin{array}{c}\text { Corrected } \\
\text { Total }\end{array}$ & 21213.710 & 123 & & & \\
\hline R Squal & & & & \\
\hline
\end{tabular}

a. $\quad$ R Squared $=0.147 *$ (Adjusted $\mathrm{R}$ Squared $=0.126$ )

From the Table 5, the Sig. values of Pretest and TA are respectively 0.000 and 0.216 , which shows that the Pretest and TA can put remarkable influence on Posttest.

TABLE VI. DESCRIPTIVES OF POSTTEST

\begin{tabular}{|c|c|c|c|c|c|c|c|c|}
\hline \multirow{2}{*}{ Class } & \multirow{2}{*}{$\mathrm{N}$} & \multirow{2}{*}{ Mean } & \multirow{2}{*}{$\begin{array}{c}\text { Std. } \\
\text { Deviation }\end{array}$} & \multirow{2}{*}{$\begin{array}{l}\text { Std. } \\
\text { Error }\end{array}$} & \multicolumn{2}{|c|}{$\begin{array}{l}95 \% \text { Confidence } \\
\text { Interval for Mean }\end{array}$} & \multirow{2}{*}{ Minimum } & \multirow{2}{*}{ naximum } \\
\hline & & & & & $\begin{array}{l}\text { Lower } \\
\text { Bound }\end{array}$ & $\begin{array}{l}\text { Upper } \\
\text { Bound }\end{array}$ & & \\
\hline A & 62 & \begin{tabular}{|l|}
53.4677 \\
\end{tabular} & 12.3670 & 1.5706 & 50.3271 & 56.6084 & 20.00 & 80.00 \\
\hline $\mathrm{B}$ & 62 & 48.6290 & 13.5250 & 1.7177 & 45.1943 & 52.0637 & 15.00 & 80.00 \\
\hline Total & 124 & 51.0484 & 13.1328 & 1.1794 & 48.7139 & 53.3828 & 15.00 & 80.00 \\
\hline
\end{tabular}

From the above three tables, we can see that the scores of the posttest in Class A are higher than that of Class B, while their pretest scores are nearly the same. We can directly see the linear relationship between the score and TA. So it is can be concluded that TA1 is superior to TA2. 
We find out from the above data analysis that the students in class A developed a relatively good understanding on how to construct a text. They had gained good control of the schematic structures of the discourse under study. The study also indicates that students in both classes did better in understanding direct information, which was the result of their good mastery of bottom-up approach in reading. Students did poorly in answering questions with indirect information, which showed their poor performance in employing discourse knowledge.

\section{B. The Influence on Students' Awareness of Self-access Learning}

With the implementation of genre-based teaching approach, students' awareness of autonomy was improved. Students were required to read additional four texts of different genres they discussed in class. They had to consult different materials by different channels, which improved their self-access learning habits.

The students are generally teacher-dependent and lack the initiative to implement learning on their own. To many of them, the classroom is the only place where they can learn English. The habit of autonomous learning provides students extra exposure to the target language. Extra exposure is especially beneficial to our students, because the limited class hour is far from for students to be successful in English acquisition. And once students have become autonomous, they are able to acquire a life-long learning skill and a habit of independent thinking, which will benefit them long after leaving university.

\section{Pedagogical Implications}

\section{1) Cultivativing Students' Awareness of Genre}

It's known that all the texts in a genre must have a uniform, invariant organization which has a combination of obligatory and optional elements. The existence of fixed, obligatory features in a particular sequence defines the limits of a genre and allows us to distinguish between different genres.

Teachers should provide as wide a variety of texts and tasks as they can, to give students practice in different kinds of reading. In addition to this, students need to be shown how the different text types are characterized by different generic structures. They should be given opportunities to compare different generic text and helped to see how the way in which information is organized within a text. So reading comprehension can be enhanced if readers are sensitized to generic structure of the text they are reading. As teachers, we should promote students' systematic, analytic and conscious understanding of literacy by teaching them both the language skills of recognizing the written forms and the reading skills of predicting content.

The study also confirmed that the analysis of different genres can effectively help students to acquire a relatively fixed text model which can be imitated and depended to improve their reading ability. Familiarizing a particular generic structure and linguistic features can not only benefit students' understanding of the whole text, but also help them in the reading comprehension tests. We know reading comprehension questions include main idea, detail, conclusion, inference, and opinion. As long as students understand the macrostructure of text, they may easily locate the main idea, the important details, conclusions and evidence. They may infer and judge based on these details.

\section{2) Suggestions for Teachers}

Teachers play a very important role in the genre-based teaching approach. Whether this approach being successful or not, to greater extent, depends on teachers' performance in class. Qualified English teachers who adopt this approach need to have an adequate mastery of knowledge of discourse and genre, techniques of text analysis, program design and material production. They should also have an understanding of the world of language classrooms.

During the implementation of this approach, teachers have to ensure that students will not regard typical realizations as fixed form-function relationships. The genre-based teaching approach must not be too prescriptive. A genre approach offers students essential information on language in use, not a means of packaging ideas.

\section{CONCLUSION}

In studies of EFL reading development, Hyon and other linguists report positive effects of genre instruction on students' understanding of text structure and overall reading effectiveness. As this s study has only shown the benefits of a short period of genre-based teaching approach on reading classroom, further research is necessary to determine to what extent students can transfer the skills acquired during genrebased teaching approach to different activity types. Genrebased teaching approaches are new, and the most effective techniques for exploiting genre models at different ability levels are still unknown. However, genre-based teaching approach has found a new practical field of Graduate English teaching in the classroom. It offers us a way forward, to look afresh at how texts are structured and offer positive help to English learners.

\section{REFERENCES}

[1] J. M. Swales, Genre Analysis: English in Academic and Research Settings. Cambridge: Cambridge University Press, 1990.

[2] V. K. Bhatia, Analysis Genre: Language use in professional settings. London: Longman, 1993

[3] M.A.K. Halliday, An Introduction to Functional Grammar. London: Edward Arnold, 1985

[4] S. Hyon, "Genre in three traditions: Implications for ESL". TESOL Quarterly 30, 1996,pp 693-722.

[5] X. B. Qin, "General Introduction on Genre Analysis”. Foreign Language, 1997(4), pp8-15 (in Chinese).

[6] W. H. Liang, "The Application and Analysis of Genre-based Teaching approach in Reading Instruction" Journal of Xi 'an International Studies University, 2010(3), pp94-98 (in Chinese)

[7] D. H. Huang, "The Application of Australian School's Genre-based Teaching Approach in English Writing Instruction". Education Research Monthly, 2014(3), pp91-95 (in Chinese). 